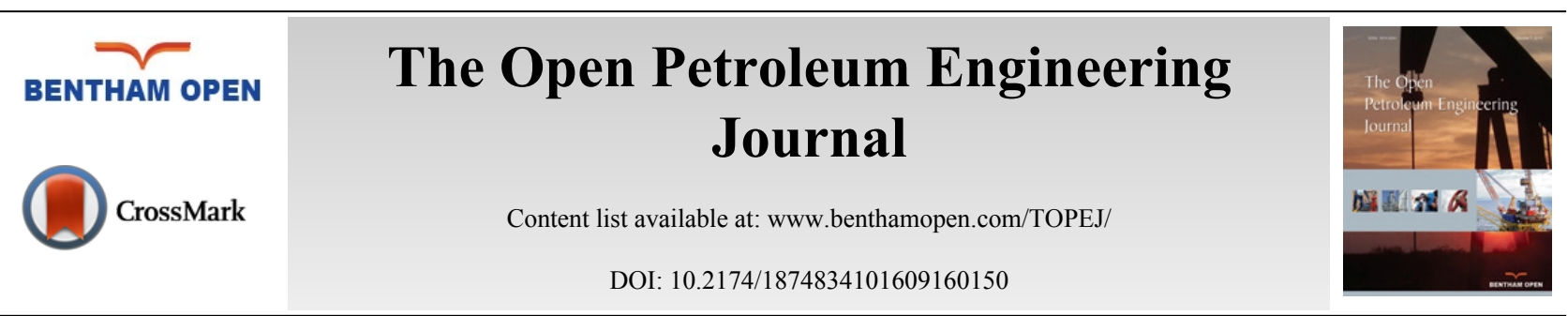

RESEARCH ARTICLE

\title{
Experimental Study on the Explosion of Gasoline-air Mixture in Reduced-scale Storage Tank
}

\author{
Yi Zhou*, Yang Du, Xiaogang Zhao, Peili Zhang and Sheng Qi \\ Department of Petroleum Supply Engineering, Logistical Engineering University, Chongqing, 401311, China
}

Received: December 1, 2015

Revised: February 15, 2016

Accepted: April 12, 2016

\begin{abstract}
Fire and explosion accidents often occur in storage tanks leading to great economic loss and serious casualties during the working, operation and maintenance. This paper established a reduced-scale storage tank experimental system, and then the explosion characteristics of gasoline-air mixture in storage tank were studied. The experimental results show that several parameters (such as concentration of gasoline-air mixture, initial temperature of gasoline-air mixture, initial $\mathrm{O}_{2}$ and $\mathrm{N}_{2}$ contained in the storage tank) have very important influence on the gasoline-air mixture explosion and its explosion products. The upper and lower explosion limits of gasoline-air mixture are about $0.86 \%$ and $4.3 \% \mathrm{HC}$ respectively according to the experimental results, and the critical explosion concentration is about $2.5 \%$ HC. The explosion of gasoline-air mixture under different initial temperatures in the concentration of $2.5 \%$ was carried out to find out that the biggest explosion overpressure is at the initial temperature of $308 \mathrm{~K}$. The concentrations of explosion products namely $\mathrm{CO}$ and $\mathrm{CO}_{2}$ are closely related to the initial concentration of gasoline-air mixture, and the critical initial concentration of gasoline-air mixture to determine the higher and lower concentrations of $\mathrm{CO}_{\text {and }} \mathrm{CO}_{2}$ in explosion products is around $2.5 \% \mathrm{HC}$. Meanwhile, the ignition of gasoline-air mixture under various concentrations of premixed $\mathrm{N}_{2}$ and $\mathrm{O}_{2}$ in the storage tank was carried out, and the results show that the ignition of gasoline-air mixture with the concentration of $2.0 \% \mathrm{HC}$ is impossible when the concentration of $\mathrm{O}_{2}$ is below $18.80 \%$.
\end{abstract}

Keywords: Explosion, Gasoline-air mixture, Reduced-scale experiments, Storage tank.

\section{INTRODUCTION}

Storage tanks often store volatile materials like gasoline which could form an explosive and flammable gaseous mixture. Fires and explosions often occur in these storage tanks. Recent statistics has shown that the over 55 cases of fire and explosion accidents, which are related to gasoline-air mixture, occurred globally between 1960 and 2003 [1]. Several catastrophic fire and explosion accidents of petroleum storage tank occurred across the world leading to great casualties, severe environmental pollution and large economic losses [2 - 4], such as the Buncefield oil depot explosion accident in London on December 2005 [5, 6], oil storage facility fire in Bayamon, Puerto Rico on October 2009 [7] and storage tank fires of PetroChina Corporation Ltd. in Dalian, China on both July and October 2010 [8].

The major studies on fire and explosion of storage tank included statistics or case studies related to storage tank accidents [1, 9 - 11], comprehensive safety assessment or evaluation of storage tank fire or explosion [12 - 15], and experimental and numerical analysis of fire and explosion in storage tank [16 - 20]. Recently, many researchers have studied explosion in confined spaces or large vessels [21 - 27], and did a lot of work in combustion limits [28 - 30]. From the studies mentioned above, it was indicated that the majority of explosion accidents that occurred in storage tanks could have been avoided by scientific guidance and careful security management. During these studies, which were evaluating storage tank accidents, researches were investigating the root causes of such accidents and summarizing the lessons learned from the safety management. However, the explosion characteristics in the storage tank were seldom involved. According the National Design Code of Petroleum Depot in China [31], the upper

\footnotetext{
* Address corresponding to this author at the Department of Petroleum Supply Engineering, Logistical Engineering University, Chongqing, 401311, China; Tel: +86-013808335056; Fax:+86-023-86731513; Email: zhouyiasd@foxmail.com
} 
explosion limit of gasoline-air mixture is roughly $4 \% \mathrm{HC}$. It is quite obscure and worrying to give such a simple number about gasoline-air mixture explosion in the storage tank without taking into consideration the configurations of the storage tank, Upper and Lower Explosion Limits of gasoline-air mixture in the storage tank, initial explosion temperature, and explosion products. In addition, among all these experimental and numerical studies mentioned above, many researches have been interested in the explosion of liquid petroleum products, methane, hydrogen, LPG or other flammable materials in storage tank but seldom have been concerned with gasoline-air mixture. Therefore, the main purpose of this paper is to study the explosion characteristics in a reduced-scale storage tank, and then to propose a practical solution to prevent storage tank accidents by inserting pure $\mathrm{N}_{2}$ into the petroleum storage tank to avoid explosion during the operation or maintenance.

\section{EXPERIMENTAL APPARATUS AND EQUIPMENT}

The experimental apparatus system is shown in Fig. (1). It is composed of three parts, namely the main experimental equipment, the testing system and the auxiliary system. The main experimental equipment contained a reduced-scale petroleum storage tank. The testing system included testing apparatus of pressure, temperature and flow rate, and the concentration collection system to measure the volume fraction of $\mathrm{HC}, \mathrm{O}_{2}, \mathrm{~N}_{2}, \mathrm{CO}$ and $\mathrm{CO}_{2}$. The auxiliary system consists of vacuum circulating pump, gasoline evaporation apparatus, ignition system, control valve, heating device, $\mathrm{N}_{2}$ supply system, etc.

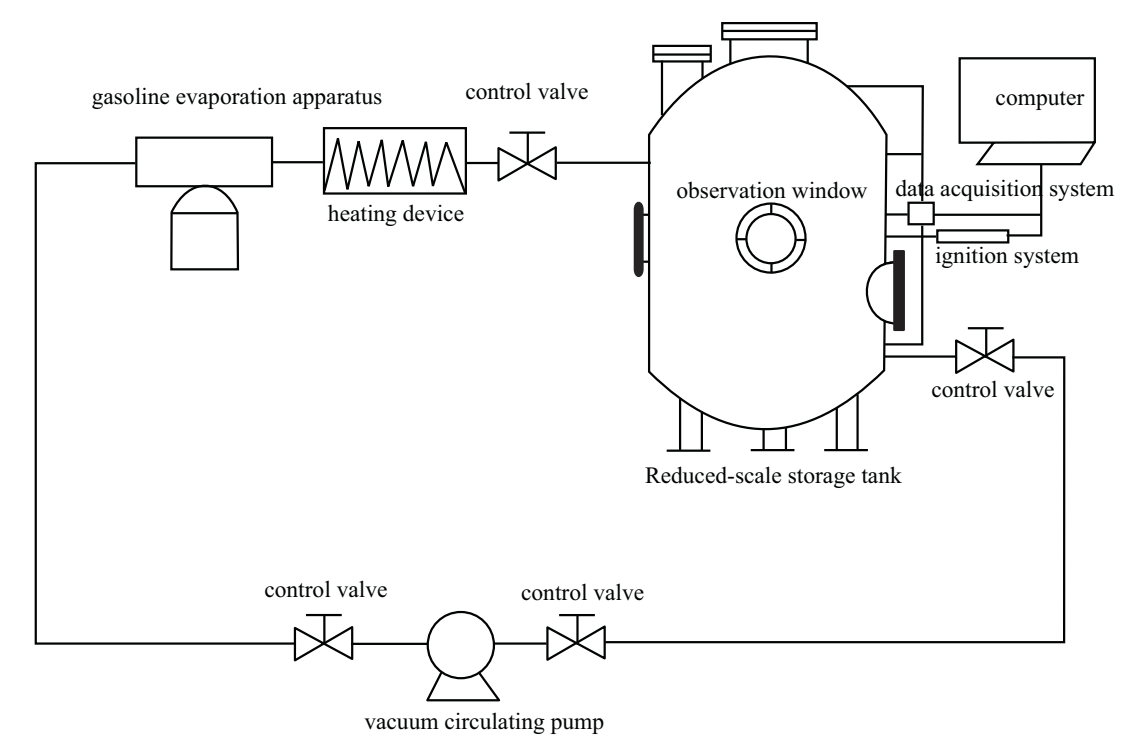

Fig. (1). Experimental apparatus and measuring system.

The reduced-scale storage tank, which is made of steel, is $1000 \mathrm{~mm}$ high with a diameter of $1000 \mathrm{~mm}$ (Fig. 2). The thickness of tank wall is $10 \mathrm{~mm}$ to maintain the safety aspects during the experiment, and the total volume of the tank is $2.03 \mathrm{~m}^{3}$. In order to observe the explosion or flame behavior occurring in the storage tank, three circular observation windows are located in the equator of the tank with a diameter of $150 \mathrm{~mm}$. Four pressure and temperature transducers are connected to the data acquisition system with an accuracy of $0.1 \%$ and dynamic response time of $10 \mathrm{~ms}$. The concentration collection system is mainly composed of a GXH-1050 infrared analyzer (Junfang physicochemical Science and Technology Institution of Beijing) and an NHA-502 automotive emission analyzer (Nanhua instruments Co. Ltd.). The concentration of the gasoline-air mixture can be obtained by the first analyzer, and concentrations of other gaseous materials $\left(\mathrm{N}_{2}, \mathrm{O}_{2}, \mathrm{CO}_{2}\right.$ and $\left.\mathrm{CO}\right)$ are measured by analyzer. The ignition system consists of a spark plug with the maximum ignition energy of 20J. Since the ignition energy and position have significant influence on the initial flame propagation, speeds and overpressures [26, 27], the ignition positions are set at three locations, namely at the top of storage tank, at the equator and at the bottom of it with the constant ignition energy of about 20J. The ignition positions do have great influence on the overpressures in closed vessels, especially for those with large value of L/D 
confined spaces and with branch configuration. But for this paper, the difference among such experiments (with ignition at the top of storage tank, at the equator and at the bottom of it) is less than $3 \%$ since the reduced-scale storage tank is a more spherical like configuration. The explosions data of storage tank under certain condition can be obtained by averaging the three ignition results. The $\mathrm{N}_{2}$ was generated by separating it from the ambient air using the nitrogen generator (Shanghai Rich gas equipment Co. LTD), and its purities could reach up to about 95\%-99\%. An electric resistance wire acting as the heating device is used to increase the initial temperature of gasoline-air mixture in the storage tank. For different desired temperature $(287 \mathrm{~K}-320 \mathrm{~K})$, it would take $15-20$ minutes to keep the temperature of gasoline-air mixture to be increased to reach this temperature in the storage tank. The gasoline-air mixture used in the experiments was produced from the $93 \mathrm{RON}$ vehicle gasoline by the gasoline evaporation apparatus. A detailed hydrocarbon analysis (DHA) of the used gasoline in this experiment is attached in the Appendix section (Table I), since the composition of gasoline varies spatially and temporally. Details and working principles of such gasoline evaporation apparatus and previous work of this preliminary experimental work could be found in [32]. The major difference between this experimental setup and ASTM's standard test is the shape of testing vessel. For ASTM's standard test, the 5-litre glass test vessel is spherical. However, the testing vessel in this experiment is a reduced-storage tank which is cylindrical. Secondly, the ignition position of ASTM's standard test is in the center of the 5-litre glass test vessel. However, the ignition positions of those storage tank accidents mostly occurred in sealed board of the floating roof which was in the vicinity of the tank wall, thus the ignition position of reduced-scale storage tank is set near the tank wall. The shape and ignition position have great influence on the values of UEL and LEL (or UFL and LFL), so the experimental setup develops a different testing vessel and ignition position to test the UEL and LEL in this particular reduced-scale storage tank.

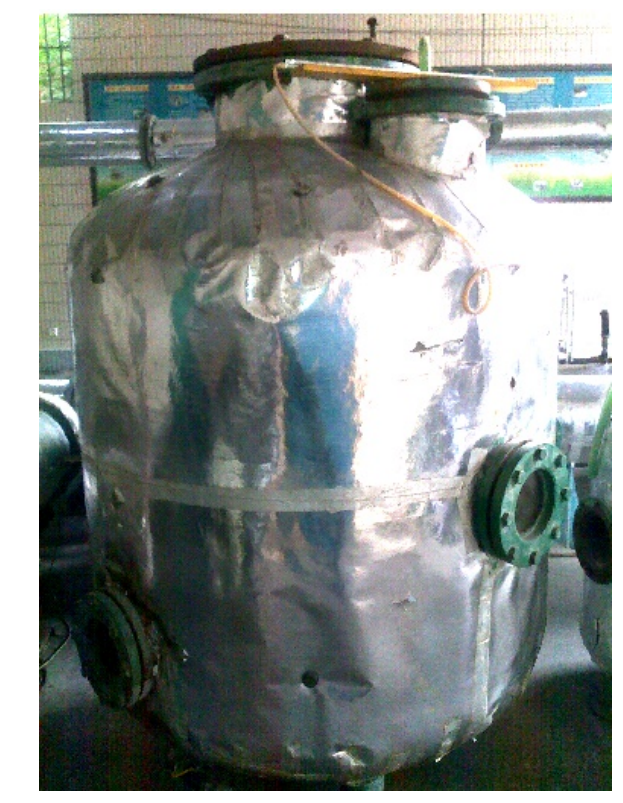

Fig. (2). Reduced-scale petroleum storage tank.

The experimental conditions were as follows: (1) the explosion characteristics in the storage tank under different concentrations of gasoline-air mixture (from $0.6 \% \mathrm{HC}$ to $5.0 \% \mathrm{HC}$ ) at the temperature of $300 \mathrm{~K}$; (2) the explosion characteristics in storage tank at different initial temperatures (from $287 \mathrm{~K}$ to $320 \mathrm{~K}$ ) with the concentration of $2.5 \% \mathrm{HC}$; (3) the explosion products in storage tank under different initial concentrations of gasoline-air mixture; and (4) the ignition of gasoline-air mixture with the initial concentration of $2.0 \% \mathrm{HC}$ in storage tank under different premixed concentrations of $\mathrm{O}_{2}$ and $\mathrm{N}_{2}$ in the reduced-scale storage tank.

\section{RESULTS AND DISCUSSION}

\subsection{The Effect of Concentration of Gasoline-air Mixture}

The overpressure versus time curve under the concentration of $2.0 \% \mathrm{HC}$ of gasoline-air mixture is shown in Fig. (3). From this figure, it can be observed that the overpressure increases rapidly at the beginning but decreases slowly after it 
reaches the peak value (about $500 \mathrm{~ms}$ ). This is a typical explosion overpressure curve of gasoline-air mixture. Due to the chain-reaction, a lot of active chemical reactions release a large amount of heat which is greater than the heat loss heat from the tank wall through conduction and radiation after the ignition of gasoline-air mixture. The overpressure increases rapidly within a short time from the ignition of gasoline-air mixture (from 0 to $500 \mathrm{~ms}$ ). However, the concentrations of gasoline-air mixture or $\mathrm{O}_{2}$ are insufficient for the further combustions when the overpressure reaches its peak value. After that, heat loss from tank wall is greater than the heat release from combustion reactions, so the overpressure gradually decreases at a slow pace.

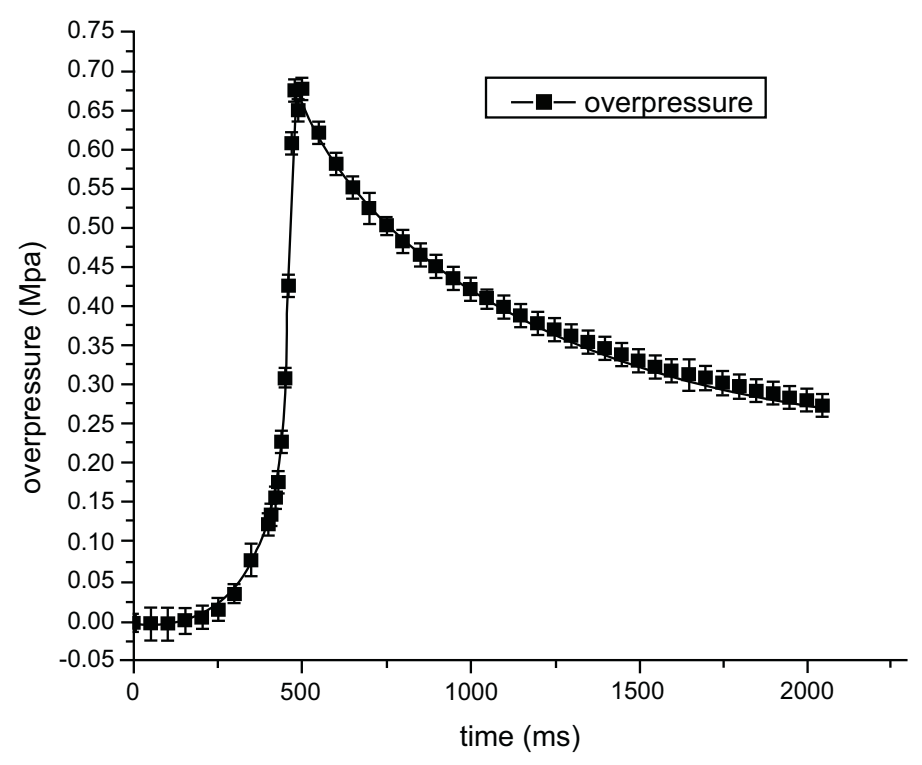

Fig. (3). The overpressure vs. time curve.

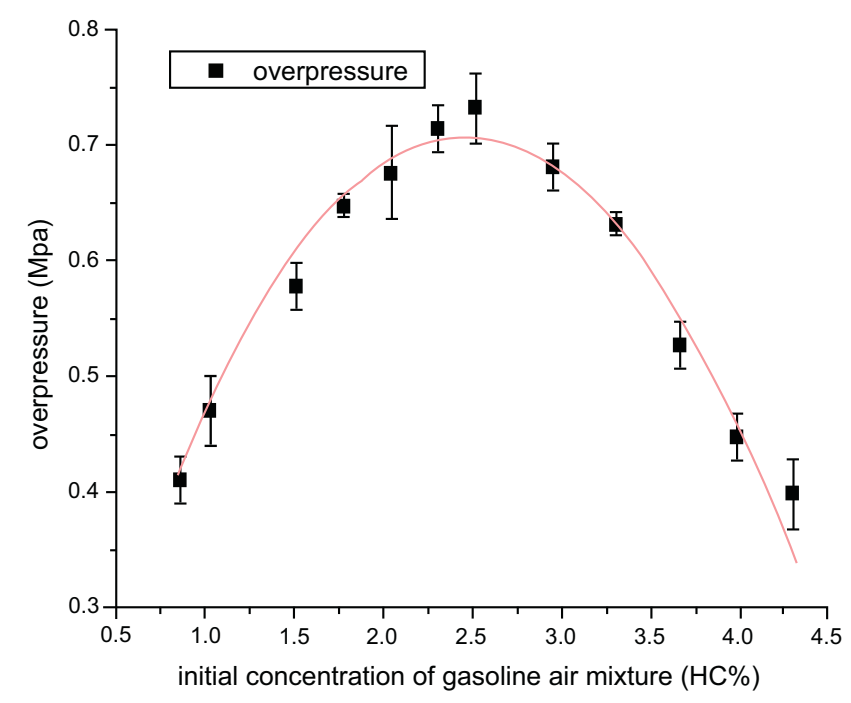

Fig. (4). The overpressure $v s$. concentration curve.

The overpressure versus concentration of gasoline-air mixture is shown in Fig. (4). This curve is a typical downward parabola. When the concentration of gasoline-air mixture is low, there is sufficient $\mathrm{O}_{2}$ to supply the completion of the combustion reaction. Therefore, the heat release rate per unit mass increases with the growth of concentration of gasoline-air mixture, and the explosion overpressure increases in accordance with that growth. When the concentration of gasoline-air mixture increases to the critical explosion concentration, the overpressure reaches its peak value. However, after that, the overpressure decreases with the continuous growth of concentration of gasoline-air mixture. This is because the amount of gasoline-air mixture exceeds the $\mathrm{O}_{2}$ supply which causes an oxygen-depleted reaction or incomplete combustion reaction. But for those experiments with concentrations lower than $0.86 \% \mathrm{HC}$ or higher than 
$4.3 \% \mathrm{HC}$, the ignition of gasoline-air mixture is impossible, the upper explosion limit and the lower explosion limit of gasoline-air mixture in reduced-scale storage tank are $0.86 \% \mathrm{HC}$ and $4.3 \% \mathrm{HC}$ respectively. The peak value of overpressure occurs under the concentration of about $2.5 \% \mathrm{HC}$, so the critical explosion concentration is about $2.5 \%$ HC. When the initial concentration of gasoline-air mixture is below $0.86 \%$ or above $4.3 \%$, the ignition of gasoline-air mixture in storage tank is impossible with 20J electrical spark. But it should be pointed out that the explosion limits might be widened as a result of increasing in the ignition energy.

\subsection{The Effect of Initial Temperature}

The overpressure versus initial temperature curve under the critical concentration (2.5\% HC) is shown in Fig. (5). Generally, the lower the initial temperature of gasoline-gas mixture (typically less than $287 \mathrm{~K}$ ), the more difficult it is to ignite the mixture. In order to carry out the experiment, the initial temperature of gasoline-air mixture in the storage tank has to be heated by preheating or other methods. The impact of initial temperature on explosion in storage tank can be significant, and it can be explained by the flame propagation velocity, which is affected back by the initial temperature as well. Higher initial temperature will increase the molecular transport speed and the energy exchange rate between molecules. As a result, it will increase the intensity of heat and mass transfer and chemical reaction in combustion. With the growth of initial temperature, the burning intensity and flame propagation velocity will increase. However, Fig. (5) shows that the impact of initial temperature on the explosion overpressure is not a linear relationship. When the initial temperature is higher than a critical temperature (about $308 \mathrm{~K}$ ), a negative growth of overpressure comes out as the initial temperature increases. It is supposed that the gasoline was not completely vaporized or just its light components were vaporized at initial temperatures lower than $310 \mathrm{~K}$, so this might cause much lower explosion pressures as expected. Besides, increasing the initial temperature will also change the composition and concentration of the hydrocarbon mixture above the liquid surface in a typical gasoline tank, which will also affect the flammability of the mixture. However, due to the restriction of experimental conditions and complying with the safety considerations, the initial temperature has not been tested beyond $324 \mathrm{~K}$.

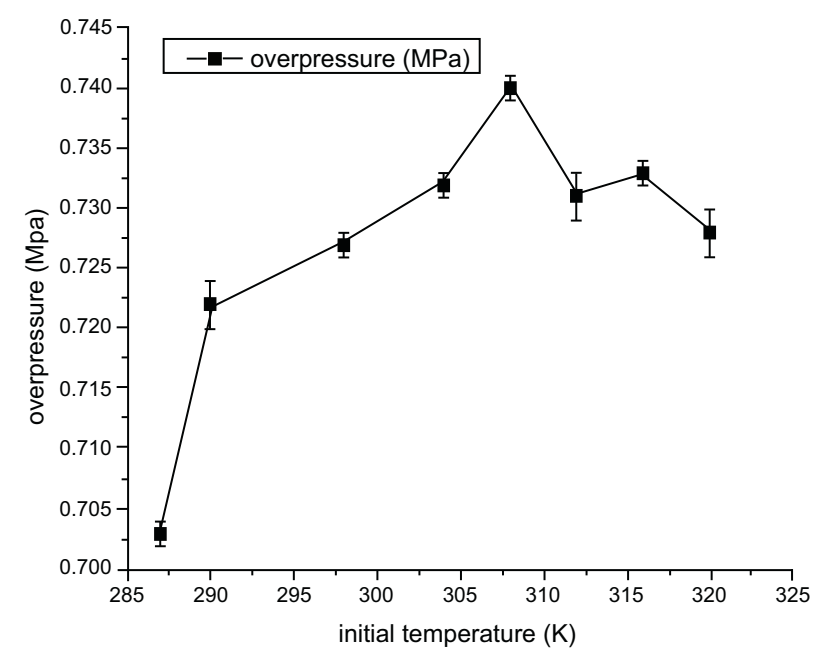

Fig. (5). The overpressure vs. initial temperature curve.

\subsection{The Effect of Concentration of Gasoline-air Mixture on Explosion Products}

The concentration curve of explosion products versus initial concentration of gasoline-air mixture is shown in Fig. (6). It can be seen that the concentration of $\mathrm{CO}_{2}$ in the explosion products decreases with the increase of concentration of initial gasoline-air mixture, while the concentration of $\mathrm{CO}$ increases. As mentioned above, the critical explosion concentration of gasoline-air mixture in the reduced-scale storage tank is about $2.5 \% \mathrm{HC}$, which is also the intersection concentration of $\mathrm{CO}$ and $\mathrm{CO}_{2}$ in the explosion products. When the initial concentration of gasoline-air mixture is larger than $2.5 \% \mathrm{HC}$, the concentration of $\mathrm{CO}$ in explosion products is higher than that of $\mathrm{CO}_{2}$. However, if the initial concentration of gasoline-air mixture is less than $2.5 \% \mathrm{HC}$, the concentration of $\mathrm{CO}_{2}$ in explosion products is higher than that of $\mathrm{CO}$. This is because when the ignition starts at a low initial concentration of gasoline-air mixture there is sufficient oxygen to support the complete combustion of gasoline-air mixture. On the contrary, when the explosive reaction is at a high initial concentration of gasoline-air mixture, there is not enough oxygen to support full used 
oxidation of gasoline-air mixture and this leads to a higher concentration of $\mathrm{CO}$ and lower concentration of $\mathrm{CO}_{2}$. When the initial concentration of gasoline-air mixture is near the upper explosion limit of $4.3 \%$, only the slow deflagration reaction occurs. Meanwhile, when the concentration of $\mathrm{O}_{2}$ is very small, the reaction is stopped. At that point, the explosion products contain high concentrations of $\mathrm{O}_{2}$ and $\mathrm{CO}$ and a low concentration of $\mathrm{CO}_{2}$.

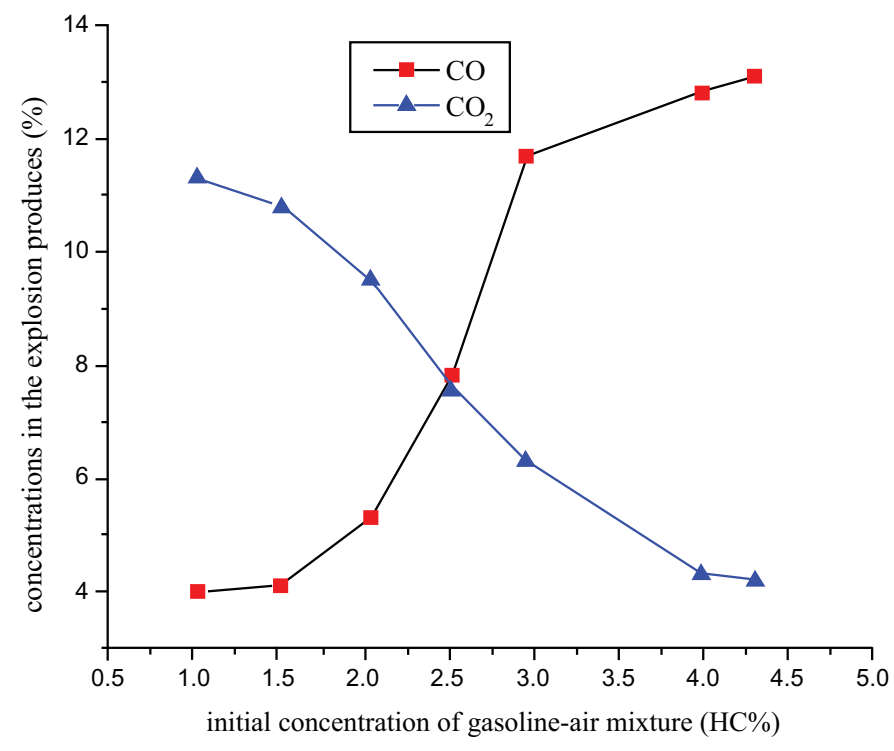

Fig. (6). The concentration curve of explosion products $v s$. initial concentration of gasoline-air mixture.

\subsection{The Effect of $\mathrm{O}_{2}$ and $\mathrm{N}_{2}$ Concentrations in the Storage Tank}

The ignition of gasoline-air mixture in the reduced-scale storage tank becomes a challenge with decreasing the concentration of $\mathrm{O}_{2}$, so it may be a good technique to prevent explosion hazards in the storage tanks by diluting the gasoline-air mixture and $\mathrm{O}_{2}$. Several experiments were carried out to find out the maximum concentration of $\mathrm{O}_{2}$ that would lead to an ignition of gasoline-air mixture with the concentration of about $2.0 \% \mathrm{HC}$. The experimental results are shown in Table 1 which indicates that the ignition of gasoline-air mixture with the concentration of $2.0 \% \mathrm{HC}$ is impossible when the concentration of $\mathrm{O}_{2}$ is below $18.80 \%$. These experiments were only limited in the ignition of gasoline-air mixture with the concentration of $2.0 \% \mathrm{HC}$, other studies on influences of $\mathrm{N}_{2}$ amounts on ignition in different initial concentrations of gasoline-air mixture will be studied in the future work. This result provides a helpful reference to manage the safety aspects of these storage tanks and improve related fire and explosion protection techniques during the storage tank design phase. This means that it is practical to prevent fire and explosion in the storage tank by adding pure $\mathrm{N}_{2}$ to the storage tank before the operating or maintaining it.

Table 1. Ignition of gasoline-air mixture under different concentrations of $\mathrm{O}_{2}$.

\begin{tabular}{|c|c|c|c|c|c|c|}
\hline \multirow{2}{*}{ Experimental number } & \multicolumn{3}{|c|}{ Fraction concentrations before ignition } & \multicolumn{3}{|c|}{ Fraction concentrations of explosion products } \\
\cline { 2 - 7 } & $\mathbf{H C}$ & $\mathbf{O}_{2}$ & $\mathbf{N}_{2}$ & $\mathbf{C O}_{2}$ & \multicolumn{3}{|c|}{$\mathbf{C O}$} & $\mathbf{O}_{2}$ \\
\hline 1 & 1.91 & 18.51 & 79.27 & \multicolumn{3}{|c|}{ Can not ignite } \\
\hline 2 & 2.02 & 18.82 & 78.96 & & 14.09 & 0.09 \\
\hline 3 & 1.98 & 18.97 & 78.84 & 4.83 & 10.0 & 0 \\
\hline 4 & 2.03 & 19.97 & 77.80 & 7.0 & 5.37 & 4.55 \\
\hline 5 & 1.78 & 20.17 & 77.63 & 9.11 & 5.38 & 2.03 \\
\hline 6 & 1.52 & 20.15 & 77.65 & 9.0 & & \\
\hline
\end{tabular}

\section{CONCLUSION}

This paper established an experimental reduced-scale storage tank to study the parameters of gasoline-air mixture explosion. In the future work, the scale model or scale effects for these experiments will be taken into consideration, furthermore, these results in the reduced-scale storage tank can be applied to full scale tank. Through experiments and 
analysis, the following conclusions were obtained:

1. The explosion limit of gasoline-air mixture in the reduced-scale storage tank can be ranged from $0.86 \%$ to $4.3 \%$ $\mathrm{HC}$, which are known as the UEL and LEL. The maximum overpressure of gasoline-air mixture in the storage tank is mainly influenced by the initial concentration of gasoline-air mixture, and the critical concentration of explosion is around $2.5 \% \mathrm{HC}$. The maximum explosion overpressure can be reduced when the concentration of gasoline-air mixture is greater than or less than the critical one.

2. The relationship between the initial temperature and the explosion overpressure is not a linear relationship. If the initial temperature is higher than a critical temperature (around $308 \mathrm{~K}$ ), a negative growth of overpressure comes out as the increase in initial temperature. However, due to the restriction of experimental conditions, the initial temperature was not tested beyond $324 \mathrm{~K}$. The effect of higher initial temperature on the explosion overpressure needs to be further studied.

3. The critical initial gasoline-air mixture concentration of $2.5 \% \mathrm{HC}$ also exists which could determine the concentrations in the explosion products. If the initial concentration of gasoline-air mixture is less than such value, the concentration of $\mathrm{CO}_{2}$ is higher than that of $\mathrm{CO}$. However, if the initial concentration is higher than the critical value, the concentration of $\mathrm{CO}_{2}$ in the explosion products is lower than that of $\mathrm{CO}$.

4. The ignition of gasoline-air mixture with a concentration of about $2.0 \% \mathrm{HC}$ in the storage tank is impossible when the concentration of $\mathrm{O}_{2}$ is below $18.80 \%$, therefore it is practical to prevent explosion accidents in storage tanks during the operation or maintenance work by adding pure $\mathrm{N}_{2}$ to the storage tank.

\section{APPENDIX}

Table I. The detailed hydrocarbon analysis of $93 \mathrm{RON}$ gasoline.

\begin{tabular}{|c|c|c|c|c|}
\hline \multirow{2}{*}{ Numbers } & \multicolumn{3}{|c|}{ Atomicity } & \multirow{2}{*}{ Percentage $\%$} \\
\hline & $\mathbf{C}$ & H & $\mathbf{O}$ & \\
\hline 1 & 4 & 8 & 0 & 2.27 \\
\hline 2 & 4 & 10 & 0 & 3 \\
\hline 3 & 5 & 10 & 0 & 11.85 \\
\hline 4 & 5 & 12 & 0 & 10.09 \\
\hline 5 & 5 & 12 & 1 & 5.4 \\
\hline 6 & 6 & 6 & 0 & 0.09 \\
\hline 7 & 6 & 10 & 0 & 0.93 \\
\hline 8 & 6 & 12 & 0 & 14.97 \\
\hline 9 & 6 & 14 & 0 & 15.59 \\
\hline 10 & 7 & 8 & 0 & 14.45 \\
\hline 11 & 7 & 12 & 0 & 0.61 \\
\hline 12 & 7 & 14 & 0 & 4.51 \\
\hline 13 & 7 & 16 & 0 & 6.86 \\
\hline 14 & 8 & 10 & 0 & 1.2 \\
\hline 15 & 8 & 14 & 0 & 0.14 \\
\hline 16 & 8 & 16 & 0 & 0.78 \\
\hline 17 & 8 & 18 & 0 & 0.95 \\
\hline 18 & 9 & 12 & 0 & 1.56 \\
\hline 19 & 9 & 18 & 0 & 0.1 \\
\hline 20 & 9 & 20 & 0 & 0.47 \\
\hline 21 & 10 & 22 & 0 & 0.33 \\
\hline
\end{tabular}

\section{CONFLICT OF INTEREST}

The authors confirm that this article content has no conflict of interest.

\section{ACKNOWLEDGEMENTS}

Financial supports provided by the National Natural Science Foundation of China (No. 51276195) and Innovation Foundation for Postgraduate of Logistical Engineering University are gratefully acknowledged. 


\section{REFERENCES}

[1] J.I. Chang, and C-C. Lin, "A study of storage tank accidents", J. Loss Prev. Process Ind., vol. 16, pp. 51-59, 2006. [http://dx.doi.org/10.1016/j.jlp.2005.05.015]

[2] N.C. Markatos, C. Christolis, and C. Argyropoulos, "Mathematical modeling of toxic pollutants dispersion from large tank fires and assessment of acute effects for fire fighters", Int. J. Heat Mass Transfer, vol. 52, pp. 4021-4030, 2009. [http://dx.doi.org/10.1016/j.ijheatmasstransfer.2009.03.039]

[3] E. Renni, E. Krausmann, and V. Cozzani, "Industrial accidents triggered by lightning", J. Hazard. Mater., vol. 184, no. 1-3, pp. 42-48, 2010. [http://dx.doi.org/10.1016/j.jhazmat.2010.07.118] [PMID: 20817399]

[4] D. Wang, P. Zhang, and L. Chen, "Fuzzy fault tree analysis for fire and explosion of crude oil tanks", J. Loss Prev. Process Ind., vol. 26, pp. 1390-1398, 2013

[http://dx.doi.org/10.1016/j.jlp.2013.08.022]

[5] T.A. Mather, R.G. Harrison, V.I. Tsanev, D.M. Pyle, M.L. Karumudi, A.J. Bennett, G. M. Sawyer, and E. J. Highwood, "Observations of the plume generated by the December 2005 oil depot explosions and prolonged fire at Buncefield (Hertfordshire, UK) and associated atmospheric changes", Proc. R. Soc. A., vol. 463, pp. 1153-1177, 2007.

[http://dx.doi.org/10.1098/rspa.2006.1810]

[6] B.J. Devenish, and J.M. Edwards, "Large-eddy simulation of the plume generated by the fire at the Buncefield oil depot in December 2005", Proc. R. Soc. A., vol. 465, pp. 397-419, 2009. [http://dx.doi.org/10.1098/rspa.2008.0288]

[7] L.A. Godoy, and J.C. Batista-Abreu, "Buckling of fixed-roof aboveground oil storage tanks under heat induced by an external fire", Thinwalled Struct., vol. 52, pp. 90-101, 2012. [http://dx.doi.org/10.1016/j.tws.2011.12.005]

[8] B. Zheng, and G. Chen, "Storage tank fire accidents", Process Saf. Prog., vol. 30, pp. 291-293, 2011.

[9] R.K. Sharma, B.R. Gurjiar, S.R. Wate, S.P. Ghuge, and R. Agrawal, "Assessment of an accidental vapour cloud explosion: Lessons from the Indian Oil Corporation Ltd. accident at Jaipur, India", J. Loss Prev. Process Ind., vol. 26, pp. 82-90, 2013. [http://dx.doi.org/10.1016/j.jlp.2012.09.009]

[10] B. Zheng, and G.H. Chen, "Storage tank fire accidents", Process Saf. Prog., vol. 30, pp. 291-293, 2011. [http://dx.doi.org/10.1002/prs.10458]

[11] E. Renni, E. Krausmann, and V. Cozzani, "Industrial accidents triggered by lightning", J. Hazard. Mater., vol. 184, no. 1-3, pp. 42-48, 2010. [http://dx.doi.org/10.1016/j.jhazmat.2010.07.118] [PMID: 20817399]

[12] A. Shahriar, R. Sadiq, and S. Tesfamariam, "Risk analysis for oil \& gas pipelines: A sustainability assessment approach using fuzzy based bow-tie analysis", J. Loss Prev. Process Ind., vol. 25, pp. 505-523, 2012. [http://dx.doi.org/10.1016/j.jlp.2011.12.007]

[13] A. Adebayo, and A.S. Dada, "An evaluation of the causes of oil pipeline incidents in oil and gas industries in Niger Delta region of Nigeria", J. Eng. Appl. Sci. (Asian Res. Publ. Netw.), vol. 3, pp. 279-281, 2008.

[14] G. Landucci, G. Gubinelli, G. Antonioni, and V. Cozzani, "The assessment of the damage probability of storage tanks in domino events triggered by fire", Accid. Anal. Prev., vol. 41, no. 6, pp. 1206-1215, 2009 [http://dx.doi.org/10.1016/j.aap.2008.05.006] [PMID: 19819369]

[15] F. Rigas, and S. Sklavounos, "Evaluation of hazards associated with hydrogen storage facilities", Int. J. Hydrogen Energy, vol. 30, pp. 1501-1510, 2005.

[http://dx.doi.org/10.1016/j.ijhydene.2005.06.004]

[16] J. Stawczyk, "Experimental evaluation of LPG tank explosion hazards", J. Hazard. Mater., vol. 96, no. 2-3, pp. 189-200, 2003. [http://dx.doi.org/10.1016/S0304-3894(02)00198-X] [PMID: 12493208]

[17] P. Li, J. Li, S. Zhao, L. Kong, and Y. Zhai, "Research on the danger of fires in oil tanks with sulfur", Fire Saf. J., vol. 40, pp. 331-338, 2005. [http://dx.doi.org/10.1016/j.firesaf.2005.02.005]

[18] N. Paltrinieri, G. Landucci, M. Molag, S. Bonvicini, G. Spadoni, and V. Cozzani, "Risk reduction in road and rail LPG transportation by passive fire protection", J. Hazard. Mater., vol. 167, no. 1-3, pp. 332-344, 2009 [http://dx.doi.org/10.1016/j.jhazmat.2008.12.122] [PMID: 19188020]

[19] J.X. Wen, V.C. Madhav Rao, and V.H. Tam, "Numerical study of hydrogen explosions in a refueling environment and in a model storage room", Int. J. Hydrogen Energy, vol. 35, pp. 385-394, 2010. [http://dx.doi.org/10.1016/j.ijhydene.2009.10.052]

[20] J. Zheng, H. Bie, P. Xu, H. Chen, P. Liu, X. Li, and Y. Liua, "Experimental and numerical studies on the bonfire test of high-pressure hydrogen storage vessels", Int. J. Hydrogen Energy, vol. 35, pp. 8191-8198, 2010. [http://dx.doi.org/10.1016/j.ijhydene.2009.12.092]

[21] J. Kindracki, A. Kobiera, G. Rarata, and P. Wolanski, "Influence of ignition position and obstacles on explosion development in methane-air mixture in closed vessels", J. Loss Prev. Process Ind., vol. 20, pp. 551-561, 2007 [http://dx.doi.org/10.1016/j.jlp.2007.05.010] 
[22] D.J. Park, Y.S. Lee, and A.R. Green, "Experiments on the effects of multiple obstacles in vented explosion chambers", J. Hazard. Mater., vol. 153, no. 1-2, pp. 340-350, 2008. [http://dx.doi.org/10.1016/j.jhazmat.2007.08.055] [PMID: 17904284]

[23] D. Razus, V. Brinzea, M. Mitu, C. Movileanu, and D. Oancea, "Temperature and pressure influence on maximum rates of pressure rise during explosions of propane-air mixtures in a spherical vessel", J. Hazard. Mater., vol. 190, no. 1-3, pp. 891-896, 2011. [http://dx.doi.org/10.1016/j.jhazmat.2011.04.018] [PMID: 21514044]

[24] D. Razus, C. Movileanu, V. Brinzea, and D. Oancea, "Explosion pressures of hydrocarbon-air mixtures in closed vessels", J. Hazard. Mater., vol. 135 , no. $1-3$, pp. 58-65, 2006.

[http://dx.doi.org/10.1016/j.jhazmat.2005.10.061] [PMID: 16386834]

[25] D. Razus, C. Movileanua, and D. Oancea, "The rate of pressure rise of gaseous propylene-air explosions in spherical and cylindrical enclosures", J. Hazard. Mater., vol. 139, no. 1, pp. 1-8, 2007. [http://dx.doi.org/10.1016/j.jhazmat.2006.05.103] [PMID: 16876946]

[26] H. Phylaktou, and G.E. Andrews, "Gas explosions in long closed vessels", Combust. Sci. Technol., vol. 77, pp. 27-39, 1991. [http://dx.doi.org/10.1080/00102209108951718]

[27] H. Phylaktou, and G.E. Andrews, "The acceleration of flame propagation in a tube by an obstacle", Combust. Flame, vol. 85, pp. 363-379, 1991. [http://dx.doi.org/10.1016/0010-2180(91)90140-7]

[28] M.G. Zabetakis, Flammability Characteristics of Combustible Gases and Vapors., Bureau of Mines: Washington, DC, 1965.

[29] Ibrahim M. Algunaibet, "Flammability and volatility attributes of binary mixtures of some practical multi-component fuels", Fuel, vol. 172, pp. 273-283, 2016.

[30] F. Zhao, "Experimental Measurements and Modeling Prediction of Flammability Limits of Binary Hydrocarbon Mixtures", PhD. thesis, 2008. Texas A\&M University, College Station, TX, USA

[31] Code for Design of Oil Depots (GB50074-2002)., China Planning Press: Beijing, 2003.

[32] P. Zhang, Y. Du, Y. Zhou, S. Qi, S. Wu, and J. Xu, "Explosions of gasolineeair mixture in the tunnels containing branch configuration", J. Loss Prev. Process Ind., vol. 26, pp. 1279-1284, 2013.

[http://dx.doi.org/10.1016/j.jlp.2013.07.003]

(C) Zhou et al. ; Licensee Bentham Open

This is an open access article licensed under the terms of the Creative Commons Attribution-Non-Commercial 4.0 International Public License (CC BY-NC 4.0) (https://creativecommons.org/licenses/by-nc/4.0/legalcode), which permits unrestricted, non-commercial use, distribution and reproduction in any medium, provided the work is properly cited. 